\title{
The Life and Hard Times of Solomon Negri: An Arabic Teacher in Early Modern Europe*
}

\author{
John-Paul A. Ghobrial
}

Arabic teachers have played only minor cameo roles in the history of Orientalism. Too often, scholars have treated them as apparitions that reveal themselves for a fleeting moment in the lives of the giants they taught before they suddenly disappear again into the ether. Only in recent years have scholars started telling their stories as something more than a mere footnote in the intellectual history of early modern Orientalism. ${ }^{1}$ In some ways, this is not surprising given the nature of the sources that survive for such people, not least those whose lives began in the Ottoman Empire but whose trajectories carried them across multiple religious and political boundaries in a Europe increasingly in need of their skills as teachers and linguists. It is striking, therefore, that Solomon Negri, a teacher of Arabic in the late seventeenth and early eighteenth centuries, has managed to elude biographers for so long. For in the case of Negri, there survives not only a handful of first-hand accounts written about his own experiences in Europe but also a rich store of correspondence

* My research on Solomon Negri began as a side-interest in the course of my doctoral research. Over the course of nearly a decade, my research interests carried me in different directions but the sad tale that Negri told of his experiences in Europe drew me back time and time again. In 2015, I was invited to give lectures at the Centre for Eastern Mediterranean Studies at Central European University in Budapest and at Bernard Heyberger's seminar at the EHESS in Paris. I used these opportunities to gather my thoughts on Negri, and I am grateful to the audiences present for their comments and questions. I am also grateful to Charles Burnett, Alastair Hamilton, and Jan Loop for the kind invitation to include my paper alongside the proceedings of their conference. From 2016-2017, the Kulturwissenschaftliches Kolleg in Konstanz provided me with a stimulating environment in which to complete this research. This essay draws on research conducted for the project Stories of Survival: Recovering the Connected Histories of Eastern Christianity in the Early Modern World, which is hosted by the University of Oxford. This project has received funding from the European Research Council (ERC) under the European Union's Horizon 2020 research and innovation programme (grant agreement no. 638578).

1 See, for example, A. Hamilton, 'An Egyptian Traveller in the Republic of Letters: Josephus Barbatus or Abudacnus the Copt', Journal of the Warburg and Courtauld Institutes, 57, 1994, pp. 123-50; Orientalisme, science et controverse: Abraham Ecchellensis (1605-1664), ed. B. Heyberger, Paris, 2010. 
and writings left behind by those who knew him alongside a spate of bureaucratic and archival documents related to his travels, his employment, and even his death.

Until the recent publication of an article about him in the Oxford Dictionary of National Biography, the only accounts of Negri's life were contained in a few short entries in nineteenth-century biographical dictionaries and manuscript catalogues. ${ }^{2}$ These accounts draw on only a handful of sources, and the consequence is that they tend to offer only a limited snapshot of Negri's life at any given moment rather than a full picture of the variety and diversity of his experiences in Europe. And yet, for a man who spent over thirty years of his life in constant movement across European and Ottoman boundaries, the sources about him remain scattered today across a sundry assortment of archives, libraries, and institutions. As such, this article draws on sources about Negri that have survived in both Arabic and European languages, and it does so with a view towards offering the first comprehensive study of Negri's life and career in Europe. This array of documentation also offers what is perhaps the most detailed glimpse into the life of an Arabic teacher in eighteenth-century Europe. Negri's experiences speak to some of the themes discussed in other chapters in this volume, for example the multiple spaces in which the study of the Arabic language took place in this period (many of which were beyond traditional university centres of Orientalism), the variety of instrumentum studiorum used by Arabic teachers and students, and above all, the challenges that faced a small category of people who sought to make a livelihood from their skills in Arabic. Such individuals found themselves in a constant search for students and patrons: for many of them, teaching functioned as but one practice alongside other tasks related to language and writing such as recordkeeping, copying, translation, and piecemeal work in libraries and archives.

Perhaps what is most interesting about Negri is the way in which his life reveals something of the actual experience of being an Arabic teacher in early modern Europe. The picture he paints is not a reassuring one. Across all of his writings, a single theme crops up over and over again: disappointment with his lot, complaint about his patrons, unhappiness in his isolation, anxiety about his future, and a keen sense of not being appreciated by those around him. Why should this be the case? Was this the experience of most informants from the Ottoman Empire, or rather was it a symptom of Negri's own idiosyncrasies?

2 D. Weston, 'Negri, Solomon (bap. 1665, d. 1727)', ODNB, May 2013 [<http://www.oxforddnb.com/ view/article/105274>]. For earlier accounts, see C.F. von Schnurrer, Bibliotheca arabica, Halle, 1811, pp. 377-9; L.G. Michaud, Biographie universelle, ancienne et moderne, Paris, 1822, vol. 31, pp. 37-8; G. Graf, Geschichte der christlichen arabischen Literatur, 5 vols, The Vatican, 19441953, vol. 3, p. 108, and vol. 4, pp. 278-9, hereafter GCAL. 
To answer such questions, this article attempts to place Negri's life in a wider context of the experiences of others like him who taught Oriental languages to Europeans in this period. Because Negri is one of the few individuals known to have taught Arabic in such varied confessional contexts as Italy, Germany, and England, this article also explores how the teaching of Arabic varied in important ways in different parts of the world in the early eighteenth century.

What little we can know about Negri's early life relies mainly on the stories he told about himself, most notably in a short autobiographical work that appeared posthumously under the title Memoria Negriana. ${ }^{3}$ Although published only in 1764, the Memoria was probably written at some point around 1717 , and it corresponds, more or less, with other accounts of his life that Negri included in various letters written to his contemporaries. ${ }^{4}$ Some additional evidence also exists in the form of short notes and colophons scattered across the manuscripts that he composed, copied, or possessed during his life. Of special interest are the records of a probate case that occurred in the wake of Negri's death on 3 April 1727, which includes testimony from several individuals who knew him in his lifetime. ${ }^{5}$

From these sources, we can obtain only the most basic picture of Negri's youth in the Ottoman Empire. We learn nothing, for example, about the origins of the peculiar surname that he used in Europe. In the earliest example of his signature in Arabic, he referred to himself as 'Sulaymān b. Ya'qūb al-Shāmī al-Ṣāliḥānì'. ${ }^{6}$ In other instances, his name was recorded by contemporaries

3 G.A. Freylinghausen, ed., Memoria Negriana hoc est Salomonis Negri Damasceni vita olim ab ipsomet conscripta nunc autem accessionibus quibusdam illustrata, Halle, 1764, pp. 1-4, hereafter Memoria Negriana.

4 See, for example, the copy of a letter he wrote to the Venetian Senate in 1705 in Appendix 1 of F. Lucchetta, 'Un progetto per una scuola di lingue orientali a Venezia nel settecento', Quaderni di Studi Arabi, 1, 1983, pp. 21-22; a letter he submitted to the French ambassador in Istanbul in 1708 in the ANF, Affaires Étrangères 375, November 1708; and the collection of correspondence related to Negri that is preserved today in the Franckesche Stiftungen zu Halle.

5 These records are preserved in TNA, and they include the inventory of Negri's estate in PROB $31 / 50 / 413,26$ July 1727 , and the probate lawsuit of 'Fdellalah v Cassano and Croce' in РRов 18/41/18, 26 July 1727 .

6 This appears in the colophon of a manuscript completed in Negri's hand in 1694, which is preserved today at the $\mathrm{BL}$, MS Sloane 3035 , fol. $3^{2}$. The nisba is likely a reference to al-Șāliḥiyya, a town originally on the outskirts of Damascus but today integrated into the city proper. I am grateful to Bernard Heyberger for his advice on this matter. 
as 'Salomon Niger'; $;$ later renderings, mostly from the nineteenth century onwards, sometimes present him as 'Sulaymān al-Aswad' (Ar. aswad meaning 'black'), although it is unclear whether this usage is simply a 'back translation' from the Latin 'Negri' to the Arabic 'aswad'. If the Arabic usage does in fact predate the Latin one, then it is possible that 'Negri' referred to an Arabic kunya, or nickname, from his youth - perhaps even a reference to his complexion. At any rate, the practice of adopting a Latinized name was emblematic of how other Eastern Christians described themselves in this period. In some cases, the Latin surname had a clear relationship to an original Arabic name as was the case with the Coptic scholar Yusuf Abu Dhaqn who adopted the name 'Giuseppe Barbato' or 'Josephus Barbatus' in the late sixteenth century. ${ }^{9}$ Unfortunately, in the case of Negri, it remains difficult to identify the genealogy behind the surname he adopted in Europe.

We can be more certain when it comes to other details about Negri's early life. In the probate case that followed Negri's death, his parents were named as 'James' (Ya'qūb) and 'Setelah'. ${ }^{10}$ Neither of these names appears as an owner or patron of manuscripts in the standard catalogues of this period, making it difficult to say much more about Negri's family. For his part, he only ever refers to his family once in the Memoria when he mentions the intriguing detail that his parents were opposed to him travelling to Europe in the first place. ${ }^{11}$ More importantly, the probate case also refers to his having been born in Damascus, and baptized there on 23 February 1665. If accurate, this suggests that Negri was a member of the Melkite Church at a time when it was under the leadership of the Patriarch of Antioch, Macarius b. al-Zaīm. ${ }^{12}$ In his youth, Negri

This was how Negri's name was rendered by one of his own students, Theophilus Siegfried Bayer, in his Historia Congregationis cardinalium de propaganda fide, Regiomonte, 1721, p. 9. See also E. Conte, I maestri della Sapienza di Roma dal 1514 al 1787: i rotuli e alter fonti, Rome, 1991, vol. 2, p. 1039, where he is registered for the years 1710-1714 as 'Salomon Niger Damascenus'.

See, for example, Graf, GCAL, vol. 4, p. 279; cf., Schnurrer, Bibliotheca arabica, p. 377, where he appears as 'Salomon Al-Sadi', which is echoed in Michaud, Biographie universelle, p. 37. In other words, I have never encountered a single instance of the name 'Sulaymān alAswad' written in the Arabic script by Negri himself or by any of his contemporaries.

9 See Hamilton, 'An Egyptian Traveller in the Republic of Letters'.

10 See the responses to question 2 in TNA, РROB 18/41/18 ('Fdellalah v Cassano and Croce').

$11 \quad$ Memoria Negriana, p. 1.

12 For a wide-ranging study of Macarius and his world, see Relations entre les peoples de l'Europe orientale et les chrétiens arabes au XVII ${ }^{e}$ siècle: Macaire III Ibn al-Zaìm et Paul d'Alep: actes du I Ir colloque international, le 16 septembre 20o1, ed. I. Feodorov, Bucharest, 2012. 
almost certainly would have known Athanasius Dabbas, the Melkite Patriarch of Antioch from 1686 to 1694 and again from 1720 to $1724 \cdot{ }^{13}$ Like Negri, Dabbas had studied with the Jesuits in his youth. Later in his life, he would collaborate with Negri and the Society for Promoting Christian Knowledge (SPCK) on the publication of an Arabic New Testament, the manuscript copy of which Dabbas provided himself to the sPск. ${ }^{14}$

Negri's origins among the Melkites in Damascus reveal something of his own experiences as a student of Arabic. In general, little is known about how Arabic was taught in the Arab provinces of the Ottoman Empire in the early modern period. In part, this is because the study of Ottoman literacy itself has tended to focus on learned scholars like the ulama or particular institutions like the madrasa, neither of which reveals much about literacy across a wider segment of society. ${ }^{15}$ But in Negri's case, we have a better sense of the pedagogy to which he was exposed because he refers in the Memoria to having studied with Jesuit and Franciscan missionaries in the Ottoman Empire. Already by 1637, the Jesuits had established themselves in Damascus, mostly under the initiative of the French missionary Jérôme Queyrot (d. 1655). ${ }^{16}$ Jesuit correspondence of this period also suggests that the missionaries succeeded early on in their efforts to establish schools for local Christians at which Arabic and Greek were taught. Negri himself mentions that he studied Greek and Latin alongside Italian. ${ }^{17}$ By

13 For a sketch of Dabbas's life, see G. Levenq, 'Athanase III', in Dictionnaire d'histoire et de géographie ecclésiastiques, Paris, 1930, vol. 4, pp. 1369-76. On his support for Arabic printing in this period, see V. Tchentsova, 'Les documents grecs du XVII ${ }^{\mathrm{e}}$ siècle: pièces authentiques et pièces fausses. 4. Le patriarche d'Antioche Athanase IV Dabbâs et Moscou : en quête de subventions pour l'imprimerie arabe d'Alep', Orientalia Christiana Periodica, 79.1, 2013, pp. 173-95 ; J-P. Ghobrial, 'The Ottoman World of 'Abdallah Zakher: Shuwayr Bindings in the Arcadian Library', in The Arcadian Library: Bindings and Provenance, eds G. Mandelbrote and W. de Bruijn, Oxford, 2014, pp. 193-231.

See, for example, the reference to the Patriarch of Antioch in An Extract of Several Letters Relating to the Great Charity and Usefulness of Printing the New Testament and Psalter in the Arabick Language, London, 1725 , pp. 30-31 and passim. The work was finally published by the SPCK in 1727 .

N. Hanna, 'Literacy among Artisans and Tradesmen in Ottoman Cairo', in The Ottoman World, ed. C. Woodhead, London, 2011, pp. 319-32.

16 For a contemporary account of the establishment of the Jesuits in the Middle East, see J. Besson, La Syrie Sainte, ou la mission de Jésus et des pères de la compagnie de Jésus en Syrie, Paris, 166o. More recently, see, for example C.A. Frazee, Catholics and Sultans: The Church and the Ottoman Empire, 1453-1923, Cambridge, 1983; B. Heyberger, Les chrétiens du Proche-Orient au temps de la réforme catholique: Syrie, Liban, Palestine, XviIIe siècles, Rome, 1994.

17 Memoria Negriana, p. 1. 
1655, the Jesuits claimed some fifty students under their care. ${ }^{18}$ As such, Negri would have been exposed to a particular style of teaching that revolved around the close study of printed Catholic works that were intended to convey the rudiments of Arabic alongside the essentials of Catholic piety. These included such works as the Arabic translation of Bellarmine's doctrine, the Arabic Psalter, and a catechism presented in the form of short questions and answers. ${ }^{19}$ Even the copious missionary correspondence of this period provides only limited and anecdotal information about the actual practices used by the missionaries to teach Arabic. In 1653, for example, Adrien Parvilliers arranged for six of his best students to recite publicly extracts from Bellarmine's doctrine in Arabic. ${ }^{20}$ In another report, Nicholas Poiresson described how the missionaries' success in proselytizing owed something to the 'echoes' of children who repeated their lessons back to their parents at home. ${ }^{21}$ This form of studying Arabic relied, therefore, on a sort of rote memorization of material of a devotional and religious nature, although it is still unclear how the practices used by the Jesuits compared to those exercised by local, native teachers. Interestingly, the Memoria also suggests the possibility that language study worked in both directions: Negri claims that he educated some of the missionaries in Arabic. ${ }^{22}$ At any rate, this missionary mode of teaching Arabic represented but one of several pedagogies that Negri would encounter during his life.

As is the case with many Eastern Christians who travelled to Europe in this period, we have no clear sense of why it was that Negri left Damascus in the first place. In some ways, the journey seems unremarkable when placed within the wider context of circulation that regularly carried Eastern Christians to Europe, Russia, and even the New World, often for the purpose of alms-collecting. ${ }^{23}$ But outside this practice, it is also clear that at least some Eastern Christians were lured to Europe by false promises made to them by Europeans in the Ottoman Empire. Upon his arrival to England in 1641, Niqūlāwus b. Buțus al-Halabī wrote to Edward Pococke describing how he had been duped into coming to Europe by the German Orientalist Christian Ravius only to find

18 A. Rabbath, Documents inédits pour servir à l'histoire du christianisme en Orient, Paris, 1905-1914, vol. 2, p. 239.

19 Doctrina Christiana: al-Ta lìm al-masịhī, Paris, 1635; cf., Rabbath, Documents, vol. 2, p. 220.

20 Rabbath, Documents, vol. 2, p. 220.

$21 \quad$ Rabbath, Documents, vol. 2, p. 239.

22 Memoria Negriana, p. 1.

23 B. Heyberger, 'Chrétiens orientaux dans l'Europe catholique (XVII ${ }^{\mathrm{e}}-\mathrm{XviII}^{\mathrm{e}}$ siècles)', in Hommes de l'entre-deux: parcours individuels et portraits de groupes sur la frontière de la Méditerranée (XVI $I^{e} X X^{e}$ siècle), eds B. Heyberger and C. Verdeil, Paris, 2009, pp. 61-92. 
that his new patron offered no real prospects for him. ${ }^{24}$ In a similar account, the Maronite Hanna Dyāb described his encounters with the French antiquarian, Paul Lucas, as he travelled through Syria in 1708. As he told it, Lucas said to him:

A minister has dispatched me to this country to find someone who can read Arabic. If you come with me, I will establish you in the library of Arabic manuscripts, and you will be appointed by the King and live under his protection for all your life. You would gain many benefits. Would you like to come with me? ${ }^{25}$

In the Memoria, Negri intimates that similar promises had been made to him by the Jesuits under whom he had studied in Damascus. As he described it, the Jesuits were so impressed by his intelligence that they encouraged him to travel to Europe. At the age of eighteen, he made a journey to Jerusalem from where he continued onwards to Paris, despite his parents' opposition to him leaving. After arriving in Paris, Negri was disappointed to find that the Jesuits had misled him. In particular, they had said he would be 'educated with noblemen' and have everything he could wish for, but none of this materialised. For this reason - and for the sake of his health - he decided to part ways with the Jesuits, albeit, he writes, on friendly terms. ${ }^{26}$ No records appear to survive related to Negri's early interactions with the Jesuits, although he would harbour a deep criticism of the order - and Catholicism in general - throughout the rest of his life.

Be that as it may, the probate case filed after Negri's death suggests that, in the course of his life, Negri also told a rather different story about why he came to Europe. Soon after Negri's death, a man called 'Michael Fdellalah', claiming to be Negri's kinsman, appeared in London and pressed a case to recover what

24 The experiences of Niqūlāwus b. Buțrus al-Ḥalabī, or Nicolaus Petri of Aleppo, have been the subject of great attention recently by Hilary Kilpatrick and Gerald J. Toomer. See the edition, translation, and study of Niqūlāwus's letters in Kilpatrick and Toomer, 'Niqūlāwus al-Ḥalabī (c. 1611-c.1661): A Greek Orthodox Syrian copyist and his letters to Pococke and Golius', in Lias: Journal of Early Modern Intellectual Culture and its Sources, 43.1, 2016. I am very grateful to Hilary Kilpatrick for sharing this unpublished work with me, and for her kind and generous help with my many queries.

25 D'Alep à Paris : les pérégrinations d'un jeune Syrien au temps de Louis XIV, eds B. Heyberger, J. Lentin, and P. Fahmé-Thiéry, Paris, 2015, p. 70 ; for the Arabic see the Vatican Library, Sbath MS 254, fol. 8v. My translation.

26 Memoria Negriana, pp. 1-2. 
remained of Negri's possessions. His meagre belongings had already been taken by Bartholomew Cassano and Peter Croce, two Greeks living in London who had apparently been close friends with Negri. ${ }^{27}$ Fdellalah's appearance triggered a wide-ranging inquiry to gather as much information as possible about Negri's past, which included taking the testimony of those who had known him in London. The records of the case reveal that Negri's friends believed that Negri's migration to Europe had been incited by a threat of forced conversion to Islam. Specifically, they described how, in a chest of Negri's papers and belongings, they had discovered copies of the first letter of recommendation that Negri had carried with him from Damascus to Europe. This document was signed by the Head of the Franciscans in Aleppo, and it certified that 'Solomon Negri in or about the month of April 1688 being under fear of being forced to turn Turk and renounce Christianity fled from Damascus and went to Rome from thence to France and proceeded to Holland and afterwards to England, where he assumed and took upon him the surname of Negri'.28 Interestingly, this is not a claim that crops up in any other source related to Negri, although it does resonate perfectly with strategies used by other Eastern Christians who sometimes used stories of persecution by Muslims in this period to secure passage from the Ottoman Empire to Europe.

Whatever the context of Negri's migration, the earliest evidence of his actual presence in France dates to August 1685 when he contributed some Arabic phrases to a book of dialogues in Greek, Arabic, Turkish, and Kurdish that was compiled in Paris by the librarian and Orientalist Louis Picques. In the margins of the manuscript, Picques marked the Arabic contributions, noting that: 'ce Jacques Salomon natif de Damas a escrit l'arabe anno 1685 mense augusto.'29 Picques compiled the corresponding phrases in other languages from individuals he had encountered passing through Paris. The manuscript reflects the collaborative nature of language study in this period as well as the importance that 'dialogues' would come to play in Negri's later career as an Arabic teacher. In the Memoria, Negri claims to have studied at the Collège de Clermont, before spending four years studying philosophy and theology at the Sorbonne. At the same time, he began teaching Arabic 'privately' to various

27 On Cassano's role as a mediator between the Non-Jurors and the Orthodox church, see S. Runciman, The Great Church in Captivity: A Study of the Patriarchate of Constantinople from the Eve of the Turkish Conquest to the Greek War of Independence, Cambridge, 1968, p. 318 .

28 TNA, РROB $31 / 51 / 413$, responses to question 3.

29 BnF, Ms Arabe 4365, fol. 1. On Picques more generally, see F. Richard, 'Un érudit à la recherché de textes religieux venus d'Orient, le docteur Louis Picques (1637-1699)', in Les Pères de l'Eglise au XVII ${ }^{e}$ siècle, eds E. Bury and B. Meunier, Paris, 1993, pp. 253-75. 
students, one of whom was the Danish Orientalist, Frederick Rostgaard, then still a young man in his late teens. Rostgaard and Negri worked on a collection of Arabic proverbs, which would be published decades later in a format that contained Negri's original proverbs with notes by Rostgaard and further annotations by Johan Christian Kall, professor of Oriental languages in Copenhagen. ${ }^{30}$ Indeed, the existence of a couple of manuscript copies of these proverbs suggests that they must have played an important role throughout his teaching. ${ }^{31}$ During this period, he also began to embrace other roles: he worked as a librarian, for example, in the massive library of Jean-François-Paul Lefèvre, the Abbé de Caumartin, which was reputed to hold some seven thousand books and manuscripts. ${ }^{32}$ His work for the Abbé also coincided with a period of employment in the Bibliothèque Mazarine, during which time he made copies of several Arabic manuscripts including a commentary on the Pentateuch, ${ }^{33}$ an anonymous work of spiritual reflections on the days of the month, ${ }^{34}$ a copy of al-Ghazālī's Masālik al-nazar fı masālik al-bashar, ${ }^{35}$ and a copy of The Salvation of the Sinners by Agapius of Crete. ${ }^{36}$ Negri was also

30 Several collections of Arabic proverbs exist dating back to the eighth century. For the earliest copy of Negri's proverbs, see BL, MS Sloane 3035 with the Latin title page in Negri's hand, Proverbia Arabica maxime trivialia \& familiari sermone quotidie usurpata quae nunquam hactenus typis excussa in usum clarissimi viri ac linguarum amantissimi Friderici Rostgaard exaravit; eidemque in amicitia pignus obtulit Jacobus Salomon Damascenus, Paris, 1696. Negri renders the Arabic title as the 'Kitāb al-amthāl al-sā'irah bayn al-nās', the author of which he identifies as one 'Ibrahīm Qara al-Sayyid'. An annotated version of this same collection was published by Joannes Christianus Kallius as Arabum philosophia popularis, sive sylloge nova proverbiorum Copenhagen, 1764 .

See, for example, other copies of proverbs in Negri's hand including BL, MS Sloane 3585/1-2 and BL, MS Harley 3370, fols 80-123. On the interest in Arabic proverbs more generally, see A. Vrolijk, 'The Prince of Arabists and His Many Errors: Thomas Erpenius's Image of Joseph Scaliger and the Edition of the "Proverbia Arabica" (1614)', Journal of the Warburg and Courtauld Institutes, 73, 2010, pp. 297-325.

32 See the Catalogue des livres de la bibliothèque de feu Monseigneur Jean-François-Paul le Febvre de Caumartin, Evêque de Blois, \&cc., Paris, 1734.

BnF, Ms Arabe 83, which refers to BnF, Ms Arabe 6 and was completed in 1685 by 'Sulaymān b. Ya'qūb al-Shāmī'. For a full description, see G. Troupeau, Catalogue des manuscrits arabes: Première partie : Manuscrits chrétiens, Paris, 1972, vol. 1, p. 67. BnF, MS Arabe 126, completed on 3 Ayyār 1685; Troupeau, Catalogue, vol. 1, p. 91.

35 BnF, Ms Arabe 1455, completed in 1692.

36 BL, MS Sloane 3028, completed in Paris in 1695 (see fol. 191); on the circulation of this work in Arabic, see C. Walbiner, "Popular" Greek Literature on the Move: The Translation of Several Works of Agapios Landos of Crete into Arabic in the 17th Century', Revue des Études Sud-Est Européennes, 51, 2013, pp. 151-2. 
enlisted to complete a catalogue of the Arabic manuscripts in the Bibliothèque Royale. ${ }^{37}$ This early period in Negri's life - obscure as it is - introduces an important point about his career in Europe, namely the extent to which his teaching of Arabic was pursued alongside a range of other activities, anything from record-keeping to translation to cataloguing and managing manuscript collections. It was Negri's uncanny ability to make himself useful that best explains how he managed so quickly and effectively to integrate himself into multiple circles of patronage in Paris.

Even so, Negri's opportunities in France did not reach as far as his own high opinion of himself. Indeed, the overriding theme of the Memoria is a long woeful tale of being under-appreciated, ill on account of the European climate, and bothered by his employers, students, and friends. After living in Paris for some five years, Negri writes that he was finally offered a post in the royal library by the Abbé de Louvois. ${ }^{38}$ Yet when he found out how small the salary associated with the post was, he was so offended that he decided instead to travel onwards to England, where he appears to have arrived sometime around $1700 .^{39}$ In England, Negri managed to secure a position for himself as teacher of Arabic to students at St Paul's, at the time under the Mastership of the Orientalist John Postletwaite. ${ }^{40}$ It was also in London that Negri first came into contact with Heinrich Wilhelm Ludolf, the secretary to Prince George of Denmark who had established a Lutheran chapel at the court of St. James and nephew to the Ethiopic scholar Hiob Ludolf. ${ }^{41}$ It was this period that marked Negri's growing ties to a circle of individuals that would, over and over again, facilitate Negri's attainment of specific posts. Ludolf, for example, was closely connected

$37 \quad$ Negri must have carried this catalogue, or a copy of it, with him to England for parts of it can be found today in BL, MS Harley 3370, which was probably commissioned from Negri by Humfrey Wanley on 12 February 1725. See The Diary of Humfrey Wanley, 1715-1726, eds C.E. Wright and R.C. Wright, London, 1966, vol. 2, p. 334.

38 The dating in the Memoria becomes confused at this point. Negri dates the offer of the post at the time of the Treaty of Ryswick in 1697, but he also writes that he had been waiting five years for it, which would place his arrival in Paris in 1692. If accurate, and if he did indeed come to Paris at the age of eighteen as he also wrote in the Memoria, that would make for a date of birth in 1674 . This is not easy to reconcile with his year of baptism, which is listed in the probate case as 1665 .

39 Memoria Negriana, p. 2.

40 On Postletwaite and Arabic teaching in England, see Mordechai Feingold's contribution to this volume.

41 See B.S. Sirota, The Christian Monitors: The Church of England and the Age of Benevolence, 1680-1730, New Haven, CT, 2014, especially chapter 3 and pp. 138-9; and, more generally, D.L. Brunner, Halle Pietists in England: Anthony William Boehm and the Society for Promoting Christian Knowledge, Gottingen, 1993. 
to August Herman Francke and the Halle Pietists, and it was at his suggestion that Negri travelled to Halle to teach Arabic at Francke's recently established school for orphans. Negri would stay in Halle for a year, a period of his life that he described dismissively as a time during which he 'dealt with various things in Arabic for the sake of many students. ${ }^{42}$ For reasons that are unclear, he remained in Halle for only about a year before deciding to travel yet again, this time to Venice. He blamed 'poor health' for his decision to leave Halle.

These early years of Negri's life suggest an important revision to our understanding of the teaching of Arabic in early modern Europe. Traditionally, the history of Arabic studies has been told as a history of institutions, most notably the establishment of chairs of Oriental languages at universities across Europe from the sixteenth century onwards. As such, the history of Orientalism is often rattled off as a string of new professorships in Rome, Paris, Leiden, Cambridge, Oxford, and so on. While universities clearly played an important role in the history of academic Orientalism, Negri's experiences point to the importance of alternative spaces for Arabic study and teaching, including private and bespoke teaching to individuals. Indeed, for most of his career, Negri would teach Arabic on the margins of universities, for example to young noblemen like Rostgaard or at secondary schools such as St Paul's or the orphan school in Halle. Not only were such contexts distinct from what is usually regarded as the real centres of Orientalism, but the fact that Arabic study took place in such spaces highlights the potential for divergent modes and practices of Arabic learning to coexist alongside each other and, moreover, the potential for a more 'popular' interest in Arabic study that has so far been neglected by scholars. ${ }^{43}$

Of course, Arabic was as much a living language as a subject of study in the eighteenth century. It is interesting, therefore, that Negri's activities as a teacher of Arabic would carry him back to the Ottoman Empire when he attempted to make use of his skills in the diplomatic and mercantile networks centred around Venice. After his brief stay in Halle, Negri resumed his travels,

$42 \quad$ Memoria Negriana, p. 2.

43 I am inspired here, in part, by Pier Mattia Tommasino's fascinating study of popular interest in the Qur'ān in seventeenth-century Tuscany, 'Lire et traduire le Coran dans le Grandduché de Toscane', Dix-septième siècle, 268.3, 2015, pp. 459-80, and Mordechai Feingold's contribution to this volume. 
this time heading eastward. In 1703, Negri met a professor from Padua who brought him to the attention of a group of patricians eager to set up a new school in Venice for the instruction of Arabic and Turkish translators. To this end, he was sent to Istanbul with the Venetian bailo Carlo Ruzzini. Francesca Lucchetta has described this Venetian endeavour to set up a new school for languages in some detail. ${ }^{44}$ For his part, Negri writes in the Memoria that he spent some three years studying Turkish and Persian in the Ottoman capital, and this period of his life would prove crucial to all that followed in several ways. Firstly, Negri's interlude in Istanbul represented his first opportunity for the study of other Oriental languages, Persian but more importantly Turkish, which remained a language of greater importance than Arabic in the everyday diplomacy and trade of the Ottoman capital. Secondly, it was during his stay in Istanbul that Negri first came into contact with Ottoman modes of language study in use by the Ottoman scholars he encountered there. This was a mode of language study that was entirely different from what he had experienced as a child at the hands of Catholic missionaries in Damascus.

There remains as yet no systematic study of language learning and teaching in Istanbul in this period, but it is possible to glean a view of what was taking place from a memorandum prepared by Negri and submitted to his contacts in Venice in 1708.45 The memorandum included a list of those works that Negri identified as being necessary to the study of Arabic, Turkish, and Persian, all of which he requested should be obtained for the new school in Venice. The list consists mainly of Arabic-Turkish-Persian dictionaries and lexicons, many of which dated back to the classical age of Islamic learning such as the Muqaddimat al-adab of Zamakhsharī (d. 1075) and the Mirqät fi l-lughat al-färsiyya by al-Națanzī (d. 1103 or 1105$){ }^{46}$ There were also more recent works on Negri's list such as the Ottoman chronicle of Hoca Sa'd ad-Dīn Efendī (d. 1599) or the Süleymānnāme of 'Abd al-'Azīz Efendī Qarā Çelebizāde (d. 1657). But perhaps the most interesting feature of Negri's 'reading list' was the presence of contemporary authors, some of whom may have even been Negri's own teachers. In Istanbul, Negri began studies with an Ottoman hoca,

44 F. Lucchetta, 'Un progetto per una scuola di lingue orientali a Venezia nel settecento', Quaderni di Studi Arabi, 1, 1983, pp. 1-28.

45 For a copy of the memorandum, see the 'lista dei manoscritti orientali che il Negri si impegna di acquistare a Costantinopoli per la futura scuola di lingue orientali di Venezia', in Appendix 3 of Lucchetta, 'Un progetto per una scuola di lingue orientali a Venezia nel settecento', pp. 25-7.

46 The Mirqāt was already known to European scholars in the early seventeenth century. See, for example, A. Hamilton, “Nam Tirones Sumus” Franciscus Raphelengius' Lexicon Arabico-Latinum', Leiden, 1613, in De Gulden Passer, 66-67, 1988-1989, p. $5^{8} 3$. 
and he mentions, for example, an otherwise unknown insh $\bar{a}$ manual by one 'Abd al-Karīm Efendī. Similar works were among the manuscripts that Negri brought with him back to Europe from Istanbul, many of which are preserved today in the archive of the Franckeschen Stiftungen in Halle (AFSt/H). They include a copy of the beginning of the Persian text of Sa'di's Gulistan, ${ }^{47}$ a (now lost) Turkish dialogue written by one 'Betros Dil' of Aleppo in 1702, ${ }^{48} \mathrm{a}$ specimen of Arabic calligraphy, ${ }^{49}$ a treatise on Islamic law, ${ }^{50}$ a copy of the

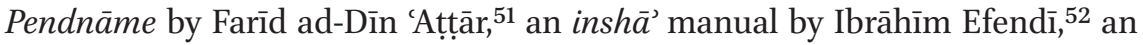
Italian-Turkish vocabulary, ${ }^{53}$ and a commentary on an Arabic-Turkish-Persian dictionary completed by Negri for the Marquis de Ferriol in Istanbul in 1704. ${ }^{54}$

The way in which Ottoman scholars connected Arabic, Persian, and Turkish is an important reminder of the distinct way in which they conceived of Arabic grammar as compared to prevailing approaches among European Orientalists. The most popular European grammar of Arabic in Negri's time, of course, was Erpenius' Grammatica Arabica (Leiden, 1613), which presented Arabic through paradigms in an approach reminiscent of Latin. The Istanbul-centred approach to Arabic was also distinct from approaches to Arabic study taking place out in the Arab provinces. François Pétis de La Croix, who taught Arabic

47 AFst/H, MS K 87 b 12-35, which was copied by Negri in 1717. This same manuscript contains other works in Ottoman Turkish with notes in the hand of Johann Callenberg. For full descriptions of the Halle manuscripts, see E. Pabst, Orientalische Handschriften im Archiv der Franckeschen Stiftungen zu Halle, Halle, 2003.

This text is referred to in BL, MS Sloane 3585 a as 'Dialogues in the Turkish language, composed by Betros Dil of Aleppo, in the year 1702 with a few glosses in Latin and Italian'. The actual work is no longer bound in the Sloane manuscript, but it seems likely it was obtained by Negri during his time in Istanbul.

49 AFst/H, MS K 87 b 3-11, which was copied by Negri in 1702.

50 AFst/H, Ms Q 24, which was dated 30 January 1661 and copied by one Muștafā ibn Ḥasan al-Khatīb.

AFst/H, MS Q 32, which includes a note by Negri to the effect that he had translated this work into Latin and wanted to publish a copy of it.

AFst/H, Ms Q 57, with the title Centum Sententiae Turcicae stilo Curiae vulgò Divanino dicto scriptae, ad discendam Calligraphiam Turcicam, quas Constantinopoli accepit à suo in Turcicis et Persicis praeceptore Ibrahim Afendi, Salomon Negri.

53 AFst/H, MS Q80, dated 1703, although it is unclear where this work was completed.

54 BL, MS Sloane 3583, with the title Vocabularium (Arabico) Turcico, Persico, metrice conscriptum, singulas voces secundum ordinem carminum Arabice, secit Elhag Mous, filius Hossan Elabbasi, qui tum opera sua merebatur apud Marchionem de Fariol, regis Galliarum ad portam Othomannicam, legatum anno Hegiarae iiiv. i.e., 1117, Solomon Negri emendavit \& Latinam interpretationem addidit, integramque auctoris seil. Shahidi, poetae apud Turcas celeberrimi prefationem Latine de integro secit, A.C. 1704, Constantinopoli. 
at the Collège Royal in Paris from 1692 to 1713, prepared an Arabic grammar of his own for use in teaching his students. Interestingly, his grammar reflected more of the interaction (and tension) between scholarly written Arabic and dialectal Arabic - or what he called 'l'arabe litteral' and 'la langue vulgaire' which he had encountered during his travels in Aleppo and Baghdad in the 1670s. ${ }^{55}$ Taken together, Erpenius, Pétis de La Croix, and Negri's engagement with Arabic reflect at least three distinct understandings of where the Arabic language sat in relation to other written and spoken registers and languages, all of which is an important reminder again of the multiple worlds of Arabic pedagogy that coexisted in this period.

Negri's aspirations for establishing the school in Venice ultimately came to nothing. His service to the Venetians lasted until about November 1708, at which point Negri approached the French and British embassies in Istanbul in search of a new post. It was at this time that Negri submitted a curious proposal to the French ambassador in Istanbul, the Marquis de Ferriol. ${ }^{56}$ Negri had heard news of the recent failed attempt of the French vice-consul in Damietta, Lenoir du Roule, to travel to Ethiopia. Du Roule had left Cairo in 1704, and he was murdered six months later near Gondar. In his letter, Negri offered a detailed analysis of Du Roule's missteps, ranging from the ostentation with which he travelled to his having enlisted an uneducated Copt as his interpreter. Instead, Negri insisted, the French king needed to enlist a 'savant' who was as well versed in the ways of the locals as he was skilled in the whole gamut of Mediterranean languages. Among his own linguistic skills, Negri referred to his talents in ancient Greek, Latin, French, Italian, Hebrew, Syriac, Arabic, Turkish and Persian. Moreover, Negri insisted that he had been trained 'in the sacred and profane sciences' and that he possessed 'all the erudition befitting a man of letters'. He also cited his vast experience of travels across Europe and Asia and, in particular, his travels through France, England, Holland, Germany, Italy, Constantinople, and Jerusalem. As if such self-promotion was not enough, Negri also appended a more detailed description of his education and the variety of posts he had held throughout his life. He wanted to use all of this experience, he concluded, to serve the French king in any way he could: he mentioned a new mission to Ethiopia but also suggested he might be the perfect replacement for Barthélemy d'Herbelot, the recently deceased chair of Syriac at the Collège Royal. The letter offers an intriguing glimpse into the continuous self-fashioning performed by Negri. Given the reputation of danger

P. Ageron, 'Le programme pédagogique d'un arabisant du Collège royal, François Pétis de La Croix (1653-1713)', Arabica, 61, 2014, pp. 406-12.

56 A copy of the proposal exists in ANF, Affaires Étrangères 375, November 1708, fols 356-67. 
associated with travelling to Ethiopia in this period, it is also a testament to the lengths to which he would go to secure any sort of employment for himself. In the Memoria, Negri writes that both Sir Robert Sutton and the Marquis de Ferriol sought to retain Negri's services but that it was he who decided he had grown tired of life in Istanbul. He left the Ottoman capital and was brought 'by unexpected chance' to Rome, sometime in $1710 .^{57}$

In Rome, Negri established contact with the powerful cardinal and bibliophile, Giuseppe Renato Imperiali, who helped Negri obtain the chair of Syriac at La Sapienza, which he held from 1710 to 1714 alongside a lectureship in Arabic at the College of the Propaganda. Strangely enough, he writes in the Memoria that he accepted these posts 'unwillingly' while waiting for a better position to become vacant at the Vatican Library. ${ }^{58}$ This is a curious way to characterize his arrival in Rome, not least because, in securing these positions, Negri had managed to achieve for himself the sort of post that other Eastern Christians in his position could only dream of. In Rome, Negri would have found himself at the heart of Catholic Orientalism and attaining the Syriac chair at the La Sapienza would have been a real achievement given that this position had long been dominated by well-connected Maronites such as Faustus Naironus Banesius or, in a later period, Joseph Assemani. ${ }^{59}$ Unlike the Maronites, whose presence in Europe benefitted from the centuries-long tradition of good relations with Rome not to mention their proximity to powerful patrons like the Barberinis, Negri had few connections to support him and so his attainment of such teaching posts was clearly to his credit. Notwithstanding his previous close links to German Protestants, Negri took to the new confessional context like a fish in water. Alongside his teaching, he proposed writing an anti-Islamic polemical work although he writes in the Memoria that he was unable to obtain copies of the manuscripts he needed to complete the project. ${ }^{60}$ During this time, he also translated a sermon by Clement XI into Arabic and Syriac, copies of which exist today in Glasgow and Moscow. ${ }^{61}$ For whatever reason, Negri's stay in Rome came to an end abruptly. After four years of waiting for a

\footnotetext{
$57 \quad$ Memoria Negriana, p. 3.

$5^{8}$ Memoria Negriana, p. 3.

59 See, for example, the list of appointments in E. Conte, I maestri della Sapienza di Roma dal 1514 al 1787: i rotuli e alter fonti, Rome, 1991, vol. 2, pp. 1038-40 for Syriac (with Negri in post from 1710-1714).

$60 \quad$ Memoria Negriana, p. 3 .

61 A copy of the sermon was completed by Negri in Halle in April 1717 for his student, Georg Jacob Kehr. This was likely the basis for GUL, Ms Hunter 325, in which Kehr's handwriting imitates that of Negri. Another copy in Negri's hand is held today in Moscow Fund 191, No. 13, fols 169-40, which probably was given to Bayer by Kehr either in Halle in 1717 or, after
} 
post at the Vatican Library, a period during which he claims he grew tired of the 'superstitions of these people' (presumably, the Catholics), Negri decided to leave Rome. He told his colleagues in Rome that he planned to return to Syria but instead he decided to travel back to England. ${ }^{62}$

Back in England, Negri renewed his contacts with the German Lutheran community in London, and they encouraged him once again to return to Halle to teach Arabic. The Memoria suggests that Negri remembered with fondness the time he had spent at Halle. Mindful of the old 'friendship, humanity and Christian character' of those whom he had known in Halle, he decided that he would return there in hopes of finding 'the last stage of his life and the end of his wanderings' ${ }^{63}$ Negri spent a further sixteen months in Halle, teaching Arabic and preparing several manuscripts for publication. Although Negri describes this period of his life in depressing tones in the Memoria - he writes that he never became accustomed to the climate, food, or drink in Halle, and that he continually experienced poor health - the manuscript evidence surviving from this second stay in Halle reflects a period of intense teaching and collaboration with his students who included (during this and the earlier stay in Halle) the likes of Christian Benedikt Michaelis, Johann Heinrich Callenberg, Theophilus Siegfried Bayer, Georg Jacob Kehr, and Johann Gottfried Lakemacher. The close relationships he developed in this period are also signalled in the strong feelings these students maintained years later for the school in Halle. William Christian Schneider, for example, had been a student in Halle from 1704 to 1708, and he later donated a Syriac manuscript to the school in Negri's honour. ${ }^{64}$ While the actual relationships that existed between Negri and his students are difficult to document in the sources, the fact that Schneider would remember his teacher in this way reveals something of the esteem in which Negri was held by at least some of his students.

It was probably at some point during this period that Negri also wrote a short treatise on the study of the Arabic language, which was included in the published version of the Memoria. ${ }^{65}$ Interestingly, his preferences in this treatise reflect neither the context of Arabic study he had first known with the missionaries in Damascus nor the Ottoman context of language study that he

1732, in St Petersburg. I am grateful to David Weston for his advice on this, and to Dmitry Morozov for providing me with details of the holdings in Russia cited here and below.

$62 \quad$ Memoria Negriana, p. 4.

63 Ibid.

64 The Syriac manuscript can be found in AFst/H, MS Q 2. In addition, an Arabic phrasebook, possibly in the hand of Negri, was also given to the school as a gift by William Christian Schneider, see AFst/H Ms Q 62.

65 See 'De studio linguae Arabicae observationes' in Memoria Negriana, pp. 4-6. 
encountered in Istanbul. Instead, Negri's observations are restricted mainly to a commentary on the essential works in use by European Orientalists in this period. He refers, for example, to Erpenius and Golius as 'the only two men who should be called most expert masters of the Arabic language in Europe'. He insists that the most useful Arabic books have been published in Holland and England, most notably Golius's Dictionary and Erpenius's Grammar as well as the 'many useful things' edited by Pococke. Although he acknowledges that some good work had been published in France - he singles out Richelieu's catechism as an example - Negri saves his greatest criticisms for Arabic works published in Italy, especially those published by the Propaganda Fide. 'The worst of all', he writes, 'are the sacred books edited by the Maronites,' which he regarded as worthless with the exception of those by Abraham Echellensis, Gabriel Sionita and George Amira.

Interestingly, Negri's treatise on the teaching of Arabic differed in fundamental ways from how Negri himself appears to have taught Arabic to his students. When reviewing the notebooks of his students, for example, it appears that Negri did not use Erpenius's Grammar or any of the works he mentioned in his treatise. Instead, he drew on a wide assortment of Arabic texts as samples for the study of Arabic much in the same way that modern Arabists read across different set texts in reading groups. Some of the texts Negri used are unsurprising. A copy of the second and third suras from the Qur'ān is preserved today in the notes of the young Callenberg. ${ }^{66}$ Other works include an Arabic version of the Psalms, dated to $1716 .{ }^{67}$ Negri also appears to have prepared his own translations of Protestant works to rival those widely disseminated by the Catholics: alongside his aforementioned translation of the sermon of Clement XI ${ }^{68}$ for example, his students also studied Negri's own Arabic translation of Luther's catechism. ${ }^{69}$ His students' notebooks reveal that he had a particular interest in the use of dialogues and conversations for

66 AFSt/H, MS K 82, which consists of a Latin translation with an Arabic-Latin glossary in the hand of Callenberg in 1716 .

67 AFst/H, MS Q 67, which is in Negri's hand and dated 1716.

68 AFst/H, Ms Q73, completed in Rome in 1711, and the other parts of the manuscript include a Turkish-Latin vocabulary and a description of the Bosphorous, perhaps dating to Negri's stay in Istanbul.

69 See AFst/H Ms Q70 for Negri's translation of Die christliche Lehre as al-Ta lìm al-masịhī, dated 23 September 1716 in Halle. This manuscript was the basis for a copy completed in Halle in 1717 by Negri's student Georg Jacob Kehr, found in AFst/H Ms Q71, fol. 36 $6^{\text {v }}$ The translation was printed years later by Callenberg as Catechismus Lutheri Minor Arabice quem olim sub ductu B. Sal. Negri Damasceni in hanc linguam transtulit et vulgavitJ. Henr. Callenberg, Halle, 1729. Another translation by Negri of Luther's Enchiridon is in GUL, MS 
teaching Arabic, which recalls his early use of proverbs with Rostgaard in the 169os. Callenberg, for example, translated a collection of German-French dialogues into Arabic under Negri's supervision, copies of which were used by other students and later published by Callenberg after Negri's death. ${ }^{70}$ It was perhaps Negri's ecumenical approach to study materials that explains the proclivities of some of his students in later years. Perhaps the most striking case is that of Callenberg who published several works intended for Arabic study from 1729, among which we find many of the same texts he had studied with Negri as well as miscellaneous documents that he had acquired himself such as a copy of a letter sent from an Archbishop in Egypt to a prince in Saxe-Gotha that reported on the travels of Wansleben through Egypt. ${ }^{71}$ While such publications are normally associated with his students, it is important to remember how large Negri's own shadow looms over these publications. That they only appeared in published form after his death - and with the names of his students attached to them - is perhaps another reason why Negri's contributions have been overlooked for so long.

In addition to the wide variety of texts used by Negri to teach Arabic, it is worth considering as well the register of Arabic that he was teaching. It is a strange thing that native speakers of Arabic were criticized by their European students for not really knowing Arabic. Some contemporaries even went so far as to denounce them as illiterate frauds. In 1611, for example, Thomas Erpenius criticised his teacher, Joseph Barbatus, for his limited knowledge of Arabic. As Erpenius put it, Barbatus had taught him 'many Arabic words', but of the 'corrupt language' spoken at the time 'by Egyptians and others', and Erpenius doubted that Barbatus could even read Arabic. ${ }^{72}$ Such comments betray a

Hunter 17, which was also completed in Halle in 1716. Another copy by Kehr is in Moscow in Fund 191, no.16, fols 88-91 and no. 23, fols 32-4.

The original work appears to be an unidentified edition of C. Mauger, Les dialogues François \& Flamends, Utrecht, 1687, perhaps that published in 1715 as Nouveau parlement, c'est à dire dialogues François-allemands, Nuremberg, 1715. It was adapted into a set of Arabic dialogues by Callenberg and published after Negri's death as Colloquia Arabica idiomatic vulgaris sub ductu B. Sal. Negri Damasceni olim composuit iamque in usum scholae suae vulgavit, Halle, 1729. An expanded version would be published in 1740. A copy of Callenberg's translation with Negri's corrections was made by Kehr in 1717, see AFst/H Ms Q 64 . The Arabic text of the letter was published under the title 'Joannis Archipresbyteri Alexandrini epistola ad Ernestum Pium Saxoniae Principem Arabice ex primigenio exemplari vulgavit', Halle, 1729. The original letter is held today in the FBG, Chart. A 101. and I was able to consult it thanks to Asaph Ben-Tov's generous and kind hospitality during my visit to Gotha.

72 The citation is from Hamilton, 'An Egyptian Traveller in the Republic of Letters', p. 128. 
fundamental misunderstanding on the part of early modern Europeans about the nature of the Arabic language itself. In part, modern scholars have sometimes repeated the prejudices of early modern Orientalists because of how few examples we have of the written Arabic used in everyday communication by people like Negri. But in the case of Barbatus, we are fortunate that a letter that he wrote to Joseph Scaliger in 1608 has survived. ${ }^{73}$ Even a cursory review of the Arabic in the letter gives a general impression that it is more dialectal and more akin to a type of Arabic that linguists today refer to as 'Middle Arabic'. When faced with such a form of written Arabic, it is not surprising that European scholars doubted the abilities of their informants, not least given the apparent disparities between such a register of Arabic and the sort of Arabic they would have encountered in the sort of manuscripts that interested them most. Yet, in recent years Arabic linguists have made a forceful, persuasive case for the argument that the traditional distinction between classical, written Arabic and dialectal, spoken Arabic is not useful for understanding a much wider spectrum of written communication that took place in a register of Arabic that retained many features of dialectal Arabic. ${ }^{74}$ Indeed, at least some European Orientalists already recognised this in the seventeenth century, as we have seen in the case of François Pétis de La Croix's understanding of Arabic in both its scholarly and dialectal forms, both of which could be written. ${ }^{75} \mathrm{In}$ other words, if Europeans were disappointed by the Arabic used by their teachers, it was more a reflection of the expectations that Europeans brought to the Arabic language than of the actual abilities of their Arabic teachers.

III

The Memoria's account of Negri's life ends in 1717, just at the moment when he had decided that he wanted to leave Halle and return to England. In England, Negri would spend the remaining ten years of his life mostly in London with occasional visits to Oxford. ${ }^{76}$ In this final stage of his life, Negri's activities as a

73 It is preserved in LUL, MS Or. 1365 (4), and I am grateful to Arnoud Vrolijk for providing me with a copy of it.

74 For the most forceful and persuasive articulation of this, see J. Lentin, Recherches sur l'histoire de la langue arabe au Proche-Orient à l'époque moderne, 1997.

75 See, for example, Aurélien Girard's comments in this volume on 'vernacular Arabic' as imagined by Antonio dall'Aquila and Domenico Germano.

76 Negri first admission to the Bodleian was recorded on 20 July 1721, see 'Admission to Bodleian, Admissions Register, 1683-1833', in the records of the Bodl. Oxf., Ms e.534, fol. $32^{\mathrm{r}}$. 
teacher faded into the background as he endeavoured to take on several new ventures. First, he became involved with the SPCK on a project to publish a revised version of the New Testament in Arabic. Alongside this work, Negri also established contacts with scholarly circles in Oxford, most notably with the Bodley's librarian Humfrey Wanley, whose diary makes several references to Negri's assistance in identifying Oriental manuscripts and inscriptions for him. ${ }^{77}$ This was also a period during which Negri translated a great deal of material from Arabic into Latin. ${ }^{78}$ Even so, his working papers (preserved today in the British Library but still neglected by scholars) are a tribute to his other interests in translation into Turkish, his exploration of different scripts and alphabets, and an interest in calendars. ${ }^{79}$ Indeed, the manuscripts dating to this period of Negri's life reveal him developing more and more into the 'man of letters' that he tried to persuade others he was. Between 1723 and 1727, Negri also served as the first interpreter of Oriental languages for the King, although it remains unclear what exactly this role comprised in this period. ${ }^{80}$ Alongside all of these roles, we do not know whether Negri continued to offer private instruction in Arabic to anyone. There has long been speculation that Negri's students included George Sale, the first English translator of the Qur'ān (1731), although no evidence exists to support this claim apart from the fact that the two men worked during the same period on the publication of the Arabic New Testament by the SPCK. Nonetheless, it is a testament to Negri's reputation as a teacher that he is widely believed today to have been the obvious teacher of such a figure as George Sale. ${ }^{81}$

77 The entries cover a period of time spanning from April 1720 to August 1725. See, for example, The Diary of Humfrey Wanley, vol. 2, pp. 39, 116, 145, 218, 334, 355, and 365 .

78 See, for example, GUL, Ms Hunter 44, Vitae et Opera Medicorum Arabicorum; Ms Hunter 133, Arabic and Latin versions of al-Razi's treatise on smallpox and measles; Ms Hunter 211, entitled Fasciculus Manuscriptorum Orientalium Videlicet; and Ms Hunter 393, with Latin translations of the lives of several oriental physicians. For full details, see J. Young and P.H. Aitken, A Catalogue of the Manuscripts in the Library of the Hunterian Museum in the University of Glasgow, Glasgow, 1908.

79 See BL, Add. MS 20,783 A/B, which comprises Negri's working papers. These papers have never been the subject of any scholarly attention, apart from a brief mention in BL catalogues including, most recently, Subject Guide to the Arabic Manuscripts in the British Library, ed. C.F. Baker, London, 2001.

80 See, for example, the records held in TNA, SP 44/123.

81 See, for example, A. Vrolijk, 'Sale, George (b. in or after 1696?, d. 1736)', ODNB, 2004; online edition, May 2015 [<http://www.oxforddnb.com/view/article/24529>], and D. Weston, 'Negri, Solomon (bap. 1665, d. 1727)', ODNB. 
The last months of Negri's life are shrouded in the same obscurity that prevents us from knowing much about his youth. The probate case that ensued after his death notes that he resided at the 'Sign of the Crown near the New Church in the Strand' and that his landlord was one William Pinfold. From time to time, he attended church services in the house of the Archimandrite Gennadius in Exeter Exchange Court near the Strand. The inventory of his possessions includes the usual assortment of objects one might expect - 'green window curtains, brass candlesticks, three pairs of shoes' - but also more cryptic objects: five long black wigs, a sword, and a silver watch, all signs that perhaps he had found at least some material comfort in the course of his itinerant wanderings. As for any signs of his long life as a teacher and scholar, all that the inventory mentions is 'three hampers full' of books. They were handed over to one 'Mr Charles Kirke' who held in his possession letters from Negri indicating that his papers should be entrusted to him. As is usually the case in such situations, the notary who drew up the inventory did not provide any further information about the books. The same goes for Mr Kirke, who never published any catalogue or description of the contents of the three hampers he inherited from Negri. Indeed, even Kirke himself remains a ghost, unknown to modern scholars and noticeable in the historical record only for the fact of his being one of a few people that Negri must have counted as a friend during the last days of his life.

For all the paper left behind by Negri and his many travels, one still struggles to capture a glimpse of the life he lived and the role he played in the study of Arabic in eighteenth-century Europe. Like so many others, his influence - on his students, on early modern Orientalism, on the societies in which he lived - was all too quickly forgotten. Perhaps the most explicit sign of this is the fate of a portrait of Negri that for some time was on display in the Bodleian Library itself. The portrait had been made by the artist Thomas Hill, the same painter who would be commissioned to make portraits of Negri's better-known contemporaries like Humfrey Wanley and William Wake. As late as 1790, the presence of the portrait was mentioned along with others on display in the Bodleian Library under the simple title, 'Salomon Negri, of Damascus, by Hill', ${ }^{2}$ Unfortunately, visitors to the Bodleian Library today will have no luck in capturing a glimpse of Negri. Whether he is dressed in Oriental or European costume, no one will ever now. For at some point after 1790, the portrait was misplaced, and its whereabouts were forgotten like so many Arabic teachers

82 A Catalogue of the Several Pictures, Statues, and Busts in the Picture Gallery, Bodleian Library, and Ashmolean Museum at Oxford, Oxford, 1790, p. 6. 
whose presence in the historiography of Orientalism remains elusive even today.

In many ways, Negri's constant complaining about his life resonates with the laments of other migrants in early modern Europe. The themes of Negri's life are common ones: the exhaustion and anxiety of an itinerant life, the constant attempt to make himself relevant and useful to his contemporaries, and amid all this hustle and bustle, a sense of constant loneliness. We know this was the case for Negri from an intriguing detail mentioned in the testimony of one of his friends in the probate case that followed his death. These friends doubted the claims of Michael Fdellalah, the man who had presented himself as Negri's kinsman. Instead, they remembered something that Negri had blurted out many years before when he exclaimed that he 'had had brothers' once in his life but 'that he had now no relation but God. ${ }^{3}$ This was an unsurprising but sad end to a life lived in perpetual motion.

83 TNA, РRов 31/51/413, responses to question 4. 